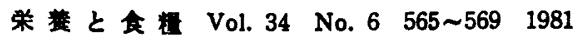

\title{
ーカガインと $\beta$-ラクトグロブリンとの加熱による複合体形成
}

\author{
土井裕 司, 井手野 祥次 \\ 伊 吹文男, 金 森 正雄

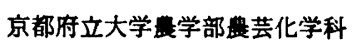

Heat Induced Complex Formation between $\alpha$-Casein and $\beta$-Lactoglobulin

\author{
Hiroshi DOI, Shoji IDENO, Fumio IBUKI, Masao KANAMORI \\ Department of Agricultural Chemistry, \\ Kyoto Prefectural University, Sakya-ku, Kyoto, Japan
}

\begin{abstract}
$\boldsymbol{\kappa}$-Casein can form the complex with $\beta$-lactoglobulin by means of heating at $90^{\circ} \mathrm{C}$ for $10 \mathrm{~min}$ in 10 $\mathrm{mM}$ imidazole- $\mathrm{HCl}$ buffer, $\mathrm{pH} 7.1$, containing $70 \mathrm{mM} \mathrm{KCl}$. The complex was dissociated by the addition of 2-mercaptoethanol, while the addition of urea did not affect on the behavior on Sephacryl S- 300 gel filtration of the complex. Therefore, the complex formation was confirmed by the Sephacryl S-300 gel filtration with $10 \mathrm{mM}$ imidazole- $\mathrm{HCl}$ buffer, $\mathrm{pH} 7.1$, containing $70 \mathrm{mM} \mathrm{KCl}$ and $4.6 \mathrm{M}$ urea, and by the sodium dodecylsulfate-polyacrylamide gel electrophoresis in the presence of 2-mercaptoethanol. Effect of carbohydrate moiety of $x$-casein was examined by heating at $70^{\circ} \mathrm{C}$ on the complex formation of $\beta$-lactoglobulin with $\boldsymbol{\alpha}$-casein components having different sugar contents. It was shown that $\boldsymbol{\kappa}$ casein component containing much more carbohydrates formed the complex with $\beta$-lactoglobulin easily. This finding may give much information to make clear the function of carbohydrate portion of $\boldsymbol{k}$ casein and the mechanism of gelation in long life milk and the utilization of whey proteins in milk industry.
\end{abstract}

(Received July 25, 1981)

牛乳たん白筫は，約 $80 \%$ のカゼインと約 $20 \%$ の秏 清たん白筫から成っている゙。カゼイン画分はカゼイン ミセルを形成してュロイド状に分散しており，このカゼ

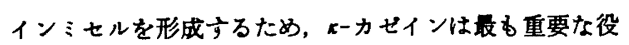
割を果たしている2)。一方，乳清たん白質の的半分は $\beta$ ラクトクロブリンであり，このたん白質は栄萑供給源と して以外に牛秏中ではなんら機能していないと考えられ ている3。

近年のように，ロングライフミルクなど各種乳製品が 開発，製品化され，そこから，たとえばロングライフミ ルク貯藏中のゲル化や沈股形成など新たな問題点る生じ てきているときにあってはあらためて乳たん白質間相互 作用の検討および考察が必要となってきているるのと考 えられる。

そこで本研究は，牛秏および乳慗品のレンニンによる 凝固性や熱安定性などを左右するといわれるいる重要な 因子である

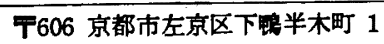

による相互作用をとりあけ゚，その諸性質を榙討するため の端緒となるるのであり, さらには, 現在のところ不明 である $\ltimes$-カセインの榶鎖機能についてす， $\beta$-ラクトク ロブリンとの相互作用を検討することによって考察を深 めよ5とするすのである。

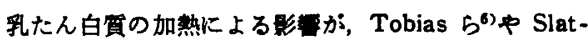
ter and Van Winkle ${ }^{7)}$ によって榙討され, 移動界面電 気泳動上で, $\beta$-ラクトクロフリンと $\alpha$-カゼインのいず れのピークあが減少することが報告されて以来，同様な

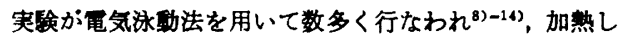
た牛乳中での $\beta$-ラクトグーフリンと $\alpha$-カゼインとの襩 合体形成を検討しよ5と試みられた。しかし，龟気泳動 実験では、Sawyer ${ }^{15)}$ McKenzie ${ }^{16)}$ の指摘するよ5 に，原理枋よび泳验バターンの複雑さのため解釈が非常 に困難である。スーカセ゚インと $\beta$-ラクトクロロブリンとの 加熱による袮合体の証明は，超遠心法によってようやく 连せられた ${ }^{172}$ が，これらの方法は，設備面，操作面，さ らには生成復合体の調慗に上る諸性筫の解明といら面か ら，実検を非常に困雄なるのにしている。 
そこで本研究においては, 简便で再現性があり, 試料 調製の容易なゲル湍過法によって $\boldsymbol{\kappa}$ ーカゼインー $\beta$-ラクト グロブリン被合体形成の証明を検討し，しかす，短時間 でのゲル㧚過を可能にするため強固なゲルを用い, $\boldsymbol{x}$-カ ゼインと $\beta$-ラクトグロブリンの加第による相互作用に 逆する研究の遂行を試みた。

\section{実 験 方 法}

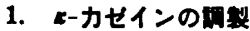

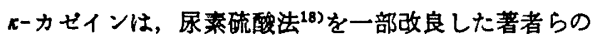
方法であって調製されささらK，DEAE-セルロースによ り糖含量の差によって分画された

\section{2. $\boldsymbol{\beta}$-ラクトグロブリン}

使用された $\beta$-ラクトグロブリンは，シグマ社より戝 入されたすのであった。

3. $\boldsymbol{x}$-カゼインー $\boldsymbol{\beta}$-ラクトグロブリン校合体形成

кーカゼインと $\beta$-ラクトグロブリンとの被合体は, 加 熱によって形成されるか，加熱条件は各実倹者によって 異なっており，また，65ㄷ 以下では複合体は形成されな いといら ${ }^{15)}$ 。そこで本研究では, 複合体形成確認のため のゲル被過用試料調製には, $90^{\circ} \mathrm{C} 10$ 分間の加熱とした。 この加熱条件下で $\beta$-ラクトクロブリンを単独で加熱す ると，大部分沈即してしまった。また，Buffer 禾には， カゼインなど乳たん白質の研究時に最もよく用いられる $70 \mathrm{mM} \mathrm{KCl}$ を含む $10 \mathrm{mM}$ イミダソール塩酸根衙液 $\mathrm{pH}$ 7.1 (以下，嘌準悢菩液とよぶ)を用いた。 $x$-カゼインと 防クトグロブリンとの重量比は，1であった。

\section{4. ゲル}

ゲル濾過用充てん剂としては, ファルマシフ社製セフ フフクリル S-300が用いられた。

5. SDS-ポリアクリルアミトゲル雪泳動

SDS-ポリフクリルフミドゲル西気泳動は, Weber and Osborn の方法20)に従って行なわれた。

6. 通元カルボキシメチル化

たん白鱼中のシスティン残基のカルボキシメチル化 は, Crestfield らの方法 ${ }^{21}$ に従って行なわれた。

\section{実験結果と考察}

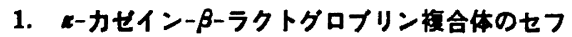 フアクリル S-300 ゲル港過}

Fig. 1 は，ハーカゼインと $\beta$-ラクトクロブリンとの混 合物を標型悢街液中で $90^{\circ} \mathrm{C} 10$ 分間加熱した試料およ び未加熱の試料の標準綬衝液を用いて溶出したときのセ

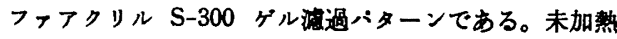
のときは, 二つのビークが認められ、それぞれの SDS-ボ リアクリルフミドゲル電気讳動より $\boldsymbol{x}$-カゼイン（peak a) と $\beta$-ラクトグロブリン (peak b) であったか，加熱

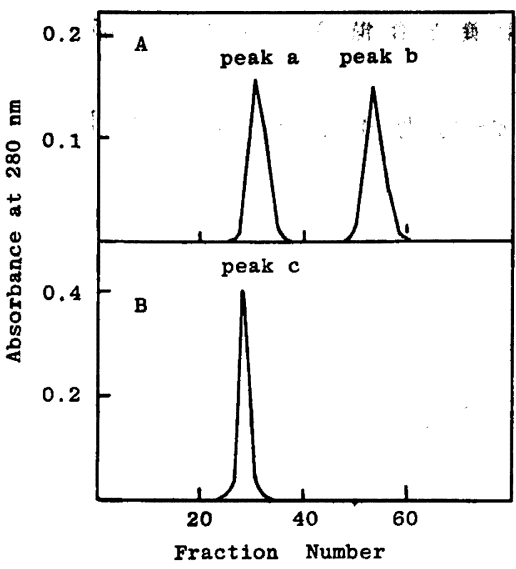

Fig. 1. Sephacryl S-300 gel filtration profiles eluted with the standard buffer of unheated and heated mixtures of $x$-casein and $\beta$-lactoglobulin.

$A$ : not heated, $B$ : heated

Each $1 \mathrm{mg}$ of $x$-casein and $\beta$-lactoglobulin was dissolved in $1 \mathrm{ml}$ of the standard buffer. The mixture was heated at $90^{\circ} \mathrm{C}$ for $10 \mathrm{~min}$ or not. The solution was applied to a Sephacryl S-300 gel column $(1.6 \times 90 \mathrm{~cm})$ and eluted with the standard buffer. A flow rate was $40 \mathrm{ml}$ per hr. One tube contained $2.5 \mathrm{ml}$.

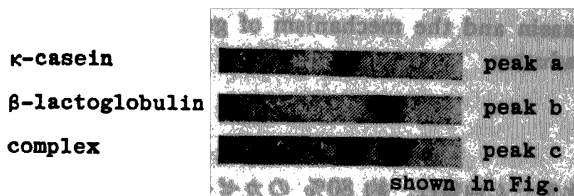

Fig. 2. SDS-Polyacrylamide gel electrophoretic patterns of $\boldsymbol{r}$-casein, $\beta$-lactoglobulin and complex between $\kappa$-casein and $\beta$ lactoglobulin.

処理によってピークが一つとなり，龟気泳動の結果，几ー カセインと $\beta$ カラクトグフフリンの混合物であった

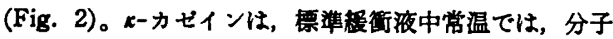
量 650,000 のポリマーとして存在しており ${ }^{199}, \beta$-ラク トグロブリンは, $\mathrm{pH} 7.0$ 以上では分子量 18,000 のモ ノマーとして存在している22)。Fig. 1 で示されたよう に，加熱処理によって $\beta$-ラクトグロブリンのビークが 消失したことから，複合体の形成が示唆された。しかし 加熱試料と $\boldsymbol{~}$-カゼインの溶出位圈がほぼ同じであるこ とから，裉合体形成を結論することはできず，片カゼイ ンと䙓合体の判別る不可能である。爪ーカセインは，尿素

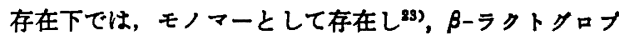

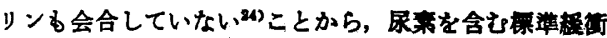




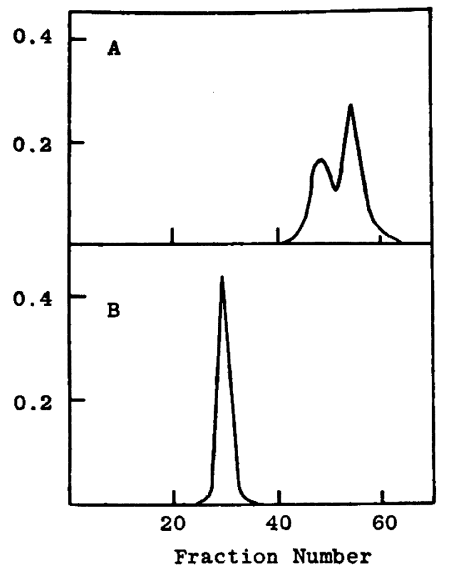

Fig. 3. Sephacryl S-300 gel filtration profiles eluted with the standard buffer containing $4.6 \mathrm{M}$ urea of unheated and heated mixtures of $\alpha$-casein and $\beta$-lactoglobulin.

A : not heated, B : heated

The mixture was prepared as described in Fig. 1. Urea was added to the solution prior to application to a Sephacryl S-300 column. Elution was carried out with the standard buffer containing $4.6 \mathrm{M}$ urea.

液での客出を行なった (Fig. 3，4)。 $x$-カゼィン, $\beta$-ラ クトグロブリンおよび両者の混合物の加熱および末加熱 試料は, $4.6 \mathrm{M}$ 尿来を含む標準程衝液での溶出によって, それぞれ異なった溶出バターンを示した (Fig. 3)。さら

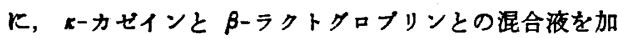
熱処理し，椧却した後，新たに $\kappa$ ーカゼインまたは $\beta$-ラ

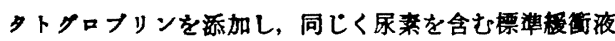
で溶出したときのゲル洞過ハターンが Fig. 4 に示され ている。Fig. 4 において, 後のピークから回収された ハーカセインおよび $\beta$-ラクトクロブリン貫は，加熱処理 後添加されたそれぞれのたん白質量にほほ等しかった。 以上の結果から， $\boldsymbol{x}$-カゼインと $\beta$-ラクトクロブリンの

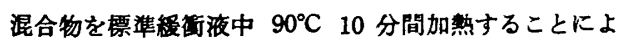
って裉合体が形成されることが示され,さらに，裇合体形 成の確認および褯合体の調製には，4.6 M 尿妻を含む標 準程街夜を用いて，セファフクリル S-300 ゲル濾過を 行ならことが有効であることが明らかにされた。

また, メルカフトトメノール存在下での加熱処理では， 䙡合体は形成されなかったし，標準緅䈃液中加熱処理に よって形成された複合体への SDS 添加および透析処理 は，ゲル減過バターンをなんら变化させなかった。さら に，スーカゼインまたは $\beta$-ラクトグロブリンのいずれか

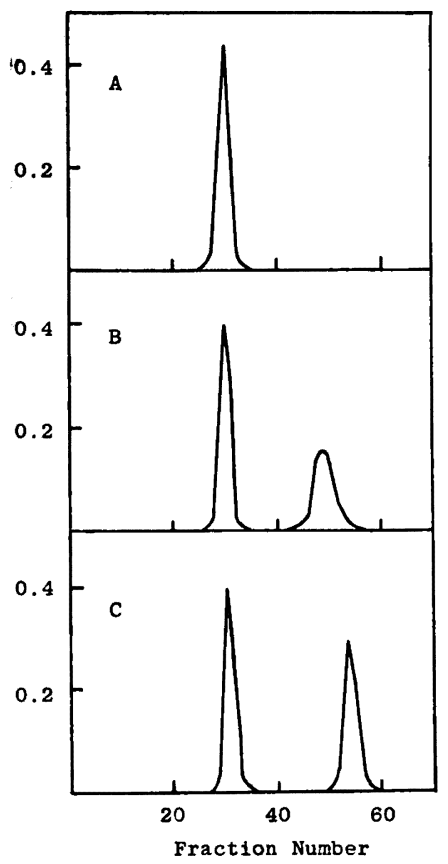

Fig. 4. Sephacryl S-300 gel filtration profiles of complex between $\kappa$-casein and $\beta$-lactoglobulin and mixture of complex and $\kappa$-casein or $\beta$-lactoglobulin.

A : complex, B : complex $+\kappa$-casein, $\quad$ : complex $+\beta$-lactoglobulin.

Complex was prepared as described in Fig. 1. $2 \mathrm{mg}$ of $n$-casein or $\beta$-lactoglobulin was added to the complex. Elution was carried out with the standard buffer containing $4.6 \mathrm{M}$ urea.

を還元カルボキシメチル化したときす，䙓合体形成は認 められなかった。

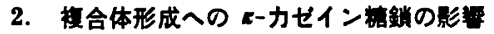

メルカブトェタール存在下での加熱処理によっては複 合体形成が㪊められず, メルカプトメノール存在下で の SDS-ポリアクリルアミドゲル龟知涾轨によって，裉 合体が解耀すること, さらには, システィン残基のカル ボキシメチル化によっても複合体が形成されなかったこ

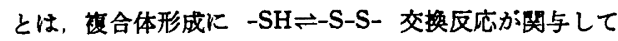
いることを示唆するすのであり，同様な結果が, Sawyer ら 25)や, Purkayastha ら

しかしながら，加熱時の客液によって複合体形成の度

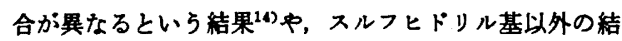
合が被合体形成に閏与していることを示唆する結果 ${ }^{273}$ あり，Wilson, Wheelock は，加熱前にカルシウムを添 加すると生乳からのと同程度の凝集性が得られることを 


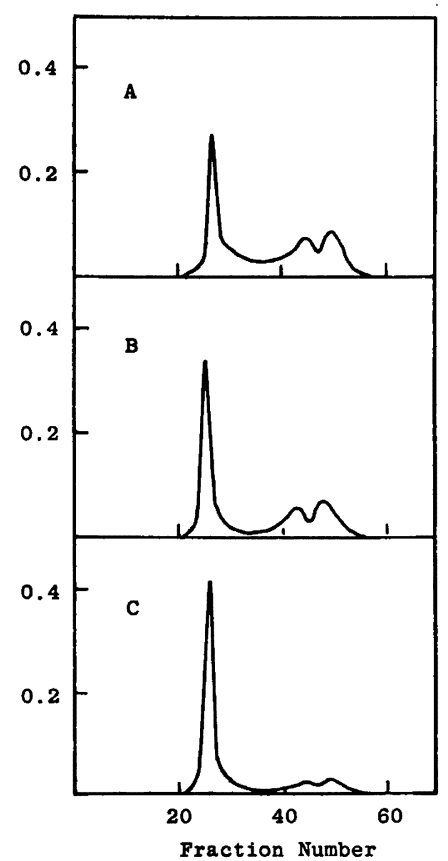

Fig. 5. Sephacryl S-300 gel filtration profiles of mixtures between $x$-casein components and $\beta$-lactoglobulin heated at $70^{\circ} \mathrm{C}$ for $20 \mathrm{~min}$.

A : P-2+ $\beta$-lactoglobulin, $\quad$ B : $P-4+\beta$-lactoglobulin, C : P-6+ $\beta$-lactoglobulin.

Each $1 \mathrm{mg}$ of $x$-casein component $(\mathrm{P}-2, \mathrm{P}-4$ or $P-6)$ and $\beta$-lactoglobulin was dissolved in $1 \mathrm{ml}$ of the standard buffer. $\alpha$-Casein component $P$ 2 is carbohydrate-free, and $P-6$ contains much more carbohydrate. ${ }^{19)}$ The solution was heated at $70^{\circ} \mathrm{C}$ for $20 \mathrm{~min}$ and urea was added.

報告しており 283，さらに，Dziuba は，相互作用にはチ ロシンやフルギニン残基が重要な役割を果たしていると 報告している29)。したがって，ハーカぜインー $\beta$-ラクトク

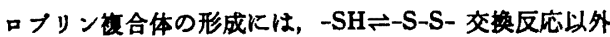
に,さまざな結合や因子が関与しているるのと考えら れる。

そこで本研究では，糖鎖部分のみを巽にする

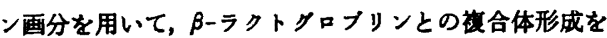
娭討することにした。Long らは，加熱温度 $68^{\circ} \mathrm{C}$ 以上 で䙓合体が形成されることを示唆している303。そこで， ハーカセインと $\beta$-ラクトクロブリンとの效合体形成にお

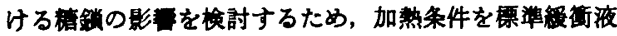
中 $70^{\circ} \mathrm{C} 20$ 分間とした。この加整条件では， $\beta$-ラクト クロブリン単独加熱でも沈段は生じなかった。加熱試料
のダル消過バターンが, Fig. 5 に示されている。 イン画分 P-2 は榶を含まず, P-4, P-6 の不に多くの 糖を含んでいる19)。複合体によるビークは，楛含量の大 きいハーカぜイン画分を用いたときのはらが大きく，褯合 体を形成していない、ーカゼイン画分および $\beta$-ラクトク ロプリンによるピークは, 糖含量の少ない $x$-カゼイン画 分を用いたときのほうが大きかった。このことは, 糖含 量の大きい $\boldsymbol{x}$-カゼイン画分汪ど $\beta$-ラクトクロブリンと 䙓合体を形成しやすいことを意味しており，䙓合体形成 において榶鎖がなんらかの成与をしていることを示して いる。爪ーカゼイと $\beta$ ーラクトグロブリンとの複合体形

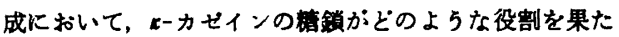
しているかは，今後の興味ある研究対象となるであろら。 また，ここでの結果は，ロングライフミルクのゲル化 機棬の解明や乳清たん白筫の利用に向けて, 榶含量の大 きい るすのである。楉含早の大きい $\boldsymbol{x}$ のカゼインを調製する ためには，現在まったく未利用である初乳を用いること が暗当である ${ }^{31}$ 。

$$
\text { 要約 }
$$

夭ーカセインは, $70 \mathrm{mM} \mathrm{KCl}$ を含む $10 \mathrm{mM}$ イミダソ 一ル㙁酸縟徨夜 $\mathrm{pH} 7.1$ 中, $90^{\circ} \mathrm{C} 10$ 分間 $\beta$-ラクトク ロブリンと加愁することによって福合体を形成すること ができる。裉合体の形成は， $4.6 \mathrm{M}$ 尿秦を含む上記悢得 液を用いてのセファフクリル S-300 ゲル㧚過と SDSポリフクリルアミドゲル電気泳项によって確認された。

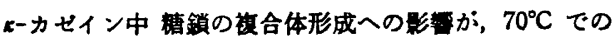

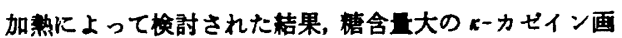
分注ど, 就合体形成能の大きいことが示された。この知

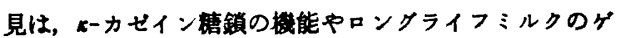
ル化楱の解明, さらには, 㐿清たん白質の利用に役立 つであろら。

本研究の一部は, 文部省科学研究费補助金 (試殹研究 56860032）によった。ここに記して感謝の意を表する。

\section{文堿}

1) Thompson, M.P. and Kiddy, C.A. : J. Dairy Sci., 47, 626 (1964)

2) Mackinlay, A.G. and Wake, R.G. : Milk Proteins II (McKenzie, H.A., ed.) 175 (1971), Academic Press (New York)

3) Evans, M.T.A. and Gordon, J.F. : Applied Protein Chemistry (Grant, R.A., ed.), 31 (1980), Applied Science Publishers (Essex)

4) Kannan, A. and Jenness, R. : J. Dairy Sci., 44, 808 (1961)

5) Morr, C.V. and Josephson, R.V. : J. Dairy Sci., 51, 1349 (1968) 
6) Tobias, J., Whitney, R.McL. and Tracy, P.H.: J. Dairy Sci., 35, 1036 (1952)

7) Slatter, W.L. and Van Winkle, Q. : J. Dairy Sci., 35, 1083 (1952)

8) McGugan, W.A., Zehren, V.F., Zehren, V.L. and Swanson, A.M. : Science, 120, 435 (1954)

9) Della Monica, E.C., Custer, J.H. and Zittle, C.A. : J. Dairy Sci., 41, 465 (1958)

10) Sawyer, W.H., Coulter, S.T. and Jeness, R. : J. Dairy Sci., 46, 564 (1963)

11) Hartman, G.H., Jr. and Swanson, A.M. : J. Dairy Sci., 48, 1161 (1965)

12) Grindrod, J. and Nickerson, T.A. : J. Dairy Sci., 50, 142 (1967)

13) Fish, N.L. and Mickelsen, R. : J. Dairy Sci. 50, 1360 (1967)

14) El-Negoumy, A.M. : J. Dairy Sci., 57, 1302 (1974)

15) Sawyer, W.H. : J. Dairy Sci., 52, 1347 (1967)

16) McKenzie, H.A. : Milk Proteins II (McKenzie, H.A., ed.), 257 (1971), Academic Press (New York)

17) Zittle, C.A., Thompson, M.P., Custer, J.H. and Cerbulis, J. : J. Dairy Sci., 45, 807 (1962)

18) Zittle, C.A. and Custer, J.H. :J. Dairy Sci., 46, 1183 (1963)
19) Doi, H., Ibuki, F. and Kanamori, M. : J. Dairy Sci., 62, 195 (1979)

20) Weber, K. and Osborn, M. : J. Biol. Chem., 244, 4406 (1969)

21) Crestfield, A.M., Moore, S. and Stein, W.H. : J. Biol. Chem., 238, 622 (1963)

22）山内邦男：牛乳の化学 (津郷友吉, 山内邦男共 著), 7, (1975), 地球社 (東京)

23) Swaisgood, H.E. and Brunner, J.R. : Biochem. Biophys. Res. Commun., 12, 148 (1963)

24) Morr, C.V. : J. Dairy Sci., 50, 1752 (1967)

25) Sawyer, W.H., Coulter, S.T. and Jenness, R. : J. Dairy Sci., 46, 564 (1963)

26) Purkayastha, R., Tessier, H. and Rose, D. : J. Dairy Sci., 50, 764 (1967)

27) Sedmerova, V., Helesicova, H. and Sicho, V. : Milchwissenschaft, 27, 481 (1972)

28) Wilson, G.A. and Wheelock, J.V. : J. Dairy Res., 39, 413 (1972)

29) Dziuba, J. : Acta Aliment. Pol., 5, 97 (1979)

30) Long, J.E., Van Winkle, Q. and Gould, J.A. : J. Dairy Sci., 46, 1329 (1963)

31) Doi, H., Park, B., Ibuki, F. and Kanamori, M. : Agric. Biol. Chem., 44, 813 (1980)

(昭和 56 年 7 月 25 日受理) 